\title{
Improving Students' Critical Thinking Ability in Exposition Text Through E-Writing
}

\author{
Dedeh Rohayati \\ Universitas Galuh \\ dedehrohayati2017@gmail.com \\ Lilies Youlia Friatin \\ Universitas Galuh \\ lilies_youlia@yahoo.co.id
}

\begin{abstract}
The high increase of electronic media supported by internet resulted in accessing all information easily. Concurrently, the requirement of thinking critically intrigued all parties to be involved in the internet environment. This research aimed at investigating whether or not there were significant mean differences of critical thinking ability in writing exposition text between students who were taught by using E-writing method and those who were given traditional method of writing. The study employed quantitative paradigm design with the type of quasi experimental and involved students which was selected purposively and formed into experimental group and control group. The primary data was the result of pre-test and posttest in the form of essays which were scored by the Holistic Critical Thinking Scoring Rubric (HTCR) developed by Facione \& Facione (2011). Based on the result of pre-test and post-test, NGain was analyzed through Man Whitney test to find out the significant mean different of students' critical thinking ability. After being analyzed by using SPSS 23, the Mann Whitney test came up with the accepted hypotheses i.e., there were significant mean differences of critical thinking ability between experiment group and control group, with mean of NGain score for experimental group was higher than control group had. The statistical output of Mann Whitney test obtained implied that students' critical thinking ability were influenced by E-writing method. The result of the study convinced that E-writing contributed greater improvement in students' critical thinking ability than the traditional method did. The finding of present study provided evidence for the effectiveness of E-writing in increasing the students' ability in thinking critically in writing exposition text.
\end{abstract}

Keywords: critical thinking, E-writing, exposition text

\section{A. Introduction}

There has been a common consensus that critical thinking is beneficial in the $21^{\text {st }}$ century. Those who can think critically are able to evaluate carefully, thinking logically, act or believe in something by offering reasons that makes sense (Chafee, McMahon, \& Stout, 2015; Facione \& Facione, 2011). This steps of thinking resulted in creating a high competitive society for meeting the world, which is global.

Recently, the ability of thinking critically has become a desirable outcome of higher education (Carmichael \& Farrel, 2012; Idris, Ariffin, \& Ishak, 2009). It leads to the urgency 
of equipping students by the comprehensive knowledge of how to analyze and evaluating. Consequently, the focused-objective of tertiary education had to include critical thinking skill to create a well-educated citizen (Çalik \& Karataş, 2019; Setyarini, Muslim, Rukmini, Yuliasri, \& Mujianto, 2018). However, the evidence has been shown by research conducted by Rohayati (2017) previously who found that students' critical thinking skill reflected in their exposition texts still needs improvement which leads to the assumption that the students has not been critical enough (Carmichael \& Farrel, 2012).

As far as it was concerned, the overwhelming need of critical thinking is getting high in facing digital world, in particular in the emergence of Information and Technology (IT) at which electronic devices are beneficial. Even, a sufficient knowledge of IT can support the other skills; one of them is critical thinking skill. It is in favor of statement from Mohd-Ali, Harun, Mahir, Massari, Mat Saad, and Simin (2018) who claim that:

"The involvement of electronic devices and internet provides the students a big opportunity to foster the skills that students would be master in 21 st century, among other, critical thinking. Furthermore, searching in internet encourage students to evaluate and synthesize the information while searching the internet. The writing and critical thinking would be relevant for their study".

The skills of critical thinking and IT aforementioned arrive at the establishment of regulation stipulated by Ministry Regulation No. 109 Year 2013 Republic of Indonesia. Besides, it is stated clearly in Higher Education Curriculum concerning critical thinking and long distance education. Consequently, critical thinking ability is required in classroom learning process such as in writing activity, in particular, writing exposition text.

Unlike Fung, To and Leung (2016) and Fung and Howe (2014) who had a great interest on utilizing group work to foster students' critical thinking, many experts (Pu \& Evans, 2019; and Lu \& Xie, 2019; see also Slater \& Groff, 2017) go on an effort of incorporating critical thinking ability and writing activity until today. The result of the study not only improve and depict the students' ability in demonstrating critical thinking, but also their writing skill. It is unfortunate that the issue of E-writing as vehicle to increase students' critical thinking has a little emphasize.

\section{E-writing as a virtual system to promote critical thinking ability}


E-writing refers to learning to write using the electronic device that is supported by internet network. It provides students a chance to develop frames for thinking and promote critical thinking (Andrew, 2009). Thus, E-writing has become an intriguing issue for practitioners both in professional and academic context.

Obviously, the use of E-writing has been popular couple years ago; and thus the predominant role of online learning, including E-writing, in particular, is a must. E-writing process is easy to construct: Turning on the internet data in the mobile phone or laptop, opening platform and follow the instruction, opening the google, collecting the data based on the topic, writing the paragraph with some fact data, translating into English (for EFL/ESL), checking the paragraph, enclosing the resources, and posting the paragraph. It is fair to say that E-writing is an effective tool for communication because it provides the user the quick action, for example, in writing persuasively.

Several distinctive features of E-writing are proposed by Andrew (2009): 1) it caters students an environment for writing with candor and reflecting their experience critically because E-writing has open and unconstrained nature; 2) E-writing is characterized by democratic atmosphere, public discourses for constructing, portraying, and reflecting on reallife learning; 3) it is more candid stream-of-consciousness discourse; 4) errors of form are more likely to be seen as typographical than grammatical; 5) E-writing can sharpen their thought for detailed writing and may be an appropriate way to participate in the process of planning writing; and 6) E-writing can be used as an individual's a draft of thoughts, insights, and expressions. These features of E-writing aforementioned are not available in traditional writing environment.

Despite the fact that critical thinking was not included in the research conducted by Djiwandono (2019), Alazemi, Sa'adi, and Al-Jamal (2019) and Ahmad and Umar (2010); they report that the availability of electronic device supporting ICT has been perceived by the students as 1) a beneficial force, 2) an attractive source, 3) learning resources, 4) a trigger for communication and collaboration, 5) teaching-learning activities, 6) a platform for the students to share and perform their thought, 7) a stimulator for writing performance. These evidence might become a motivation for teachers who find ICT daunting and the E-writing can be assumed as promising method for increasing students' critical thinking.

It is not doubtful that the involvement of internet aforementioned can become a vehicle to develop students' ability in thinking critically. In addition, the students are now considered 
as digital native who always think quickly. As a globalized society, the students' should grasp the complex role of electronic devise, for example smartphone, as well as its application. One of the application that has become popular recently, and is easy to use is WhatsApp, which is utilized in the present study. The application of WhatsApp employs internet data to provide the users an assistance of networking with others. Thus, it is suggested for all the teachers to optimize the existence of smartphone as a tool of learning (Alsaleem, 2013; Ta'amneh, 2017) with the accompaniment of blended learning or flipped learning (Zainuddin, Habiburrahim, Muluk, Keumala, 2019).

\section{Critical thinking in exposition text}

Critical, which related to critize means "question or evaluate" (Chafee, McMahon, \& Stout, 2015). Many experts of critical thinking movement also propose various definitions of critical thinking. They come up with the definition of critical thinking, i.e., as a process of evaluation to achieve the goal of producing a reasonable decision and to determine whether judgment about the truth of claim or recommendation should be accepted/ rejected (Chaffee et al., 2015; Paul \& Elder, 2010).

Regarding the aspects of critical thinking elements, it includes issue, claims (thesis), argument, reasons, data (evidence), and opinion which are reflected in persuasive writing, in particular, exposition text. As far as it as concerned, writing activity also has been considered as a device to trigger students' critical thinking. However, a prominent critical thinker should avoid another aspect of critical thinking, namely, fallacy. The fallacy pertains to a meaningless, irrelevant, and useless aspect of critical thinking which can be identified in arguments (Chaffee et al., 2015, p. 300).

Writing, which helps students to convey their ideas and as a means for written communication activity, can become a vehicle to promote students' critical thinking because it needs analytical and complex skill. In particular, as a type of persuasive writing, exposition text taught in a tertiary level also needs a complex thinking skill; and thus, it is considered as higher-level thinking and needs the ability to synthesize information (Chaffee et al., 2015).

In reality, English students still find writing activity, especially academic writing, as the most difficult lesson, even for the native English. It might be that the lack of critical thinking ability has a great contribution toward students' writing skill (Rohayati, 2017). Consequently, 
it is necessary to implement E-writing as a suitable strategy for the current student, which are digital native (Kavaliauskienė, Suchanova, \& Veličkienė, 2013).

Regarding the previous study on related topic, there are five studies conducted by Scott (2008), Brodahl, Hadjerrouit, \& Hansen, (2011), Sharadgah (2014), Romagnuolo (2015), and Ebadi and Rahimi (2018). Based on the result of questionnaires, Scott (2008) reported the success of debate in increasing students' critical thinking. The rest of previous studies explained before, except Ebadi and Rahimi (2018), did not focus on 1) the exploration of certain text, for example, exposition; and 2) the type of application on smartphone, in particular, WhatsApp. However, both of them synergized the use of technology in writing process; even though, E-writing provides a large room for students to develop their critical thinking ability rather than traditional technique.

Another result of the research revealed that the students, in particular the young ones, with high digital competence and a positive attitude towards digital tools are more positive (Romagnuolo, 2015). Yet, it is unfortunate that Brodahl et al. (2011) did carried out the issue of critical thinking in their study. The last previous research was carried out by Sharadgah (2014) and Ebadi and Rahimi (2018) who employed the experimental of research design; it reveals the desirable finding that critical thinking skill will be very effective if it is accompanied by the based-internet environment because it is relevance to the current demands.

The elaboration of the previous study explained before uncovers the fact that the studies on the use of E-writing method through WhatsApp to increase critical thinking ability is still less emphasizes. Therefore, the present study tries to fill the gap by conducting the research on the effectiveness of E-writing in increasing students' critical thinking in writing exposition text. In particular, the objectives of the study is to explore whether or not there were significant mean differences of critical thinking ability in writing exposition text between students who were taught by using E-writing method and those who were given traditional method of writing.

Drawing from explanation above, the present study is also a great contribution to support 1) the regulation established by Regulation of Education and Culture Ministry, No.109 Year 2013, Republic of Indonesia; 2) curriculum designed for higher education; and 3) motto or work culture of institution where the study carried out. 


\section{B. Research Methodology Research Design}

This quantitative study dealt with "seeking the cause", and involved statistics measurement, and tested the hypotheses (Cohen, Manion, \& Morrison, 2011). Therefore, the hypotheses is formulated: Is there any significant mean differences of critical thinking ability in writing exposition text between students who were taught by E-writing method and those who were taught by traditional method. The present study utilized quasi experimental (Creswell, 2010) with the type of pre-test post-test non-equivalent control group design.

\section{Population and Sample}

This study was administered to fourth semester students at English Department of Faculty of Teacher Training and Educational Science, in a private University in West Java, Indonesia. The sample which was taken based on researcher's judgment consisted of two small groups: experimental (20 students) and control group (20 students), at which both of groups were given pre-test and post-test.

\section{Research Instrument}

The present study involved pre-test and post-test since which was in the form of prompt writing consisting of controversial issues. It has been considered as reliable and valid as suggested by Kunkun (2015) who argues that writing assessment test of the study commits reliability because "it measures consistently both in terms of the same student on two or more separate occasions and the same task by different raters".

To begin the pre-test activity, both groups were required to write exposition text (essay) consisting of 5 paragraphs based-paper writing essay. At this stage, the student did not attend the environment of the internet access. After that, the researcher taught the writing exposition text to each group for three meeting with the different method; the experimental group had the E-writing method by using WhatsApp, which led them to have big opportunity to use the other search engine such as Google, Yahoo Mail, and Google Mail. Unlike the experimental group, the control group employed traditional method at which they were not allowed to use any device that used the internet access during the activity. The teaching program lasted for 100 minutes of each meeting. 
After finishing the treatment, both groups were given post-test in the form of prompt writing and asked to write the 5 paragraph essay. The experimental group essays of exposition text written by students in experimental group were sent via WhatsApp or e-mail. In contrary, the control group sent their essay traditionally, i.e., they wrote on a piece of paper and directly submitted to the lecturer on the spot.

\section{Data Analysis}

The students' essay were then scored by two raters; by the researcher herself and the colleague who has been trained before with a comprehensive knowledge of critical thinking in exposition text. Each essay was scored twice by the rater in order the assessment obtained a high quality.

After scoring, the process of analysis was preceded by grouping the result of pre-test and post-test into experimental and control group; and followed by counting the data with the assistance of SPSS 23 to find out NGain score of each student which indicated the difference score of pre-test and post-test. Subsequently, it was to test the normality of NGain score . The result suggested that the data were not in a normal distribution; so the non-parametric statistics was applied, in particular, Mann Whitney was utilized to find out the different mean of NGain score. In this study, the criteria was that asymp. Sig (2-tailed test) $=0,000<0,05$ resulted in the rejecting $\mathrm{H}_{0}$ and accepting of $\mathrm{H}_{1}$.

\section{Procedure of E-writing}

To obtain the fruitful result, the study was guided by several steps of E-writing. Each meeting lasted for about 100 minutes in a week; and during that time, the students were taught the concept of Critical Thinking in writing exposition text.

First of all, the researcher along with the students of experimental group made WA Group (WhatsApp Group) under the profile name of E-CThinkingdance. Subsequently, each group of students in experimental group was asked to search information from the variety of search engines such as Google platform the concept of Critical Thinking in writing, in particular, exposition text. After obtaining the intended information, they shared it in WA Group which enabled them to deliver question and comments. The forthcoming activity was to ask each group for writing an exposition text which was basically divided into three steps: 1) Pre-writing; 2) While-writing; and 3) Post-writing. Unlike the traditional writing, E- 
writing model by using WhatsApp comprised 1) Opening WhatsApp Web; 2) Searching the sources from Google; 3) Composing, and 4) Posting. Figure 1 below illustrates the steps of Ewriting through WhatsApp:

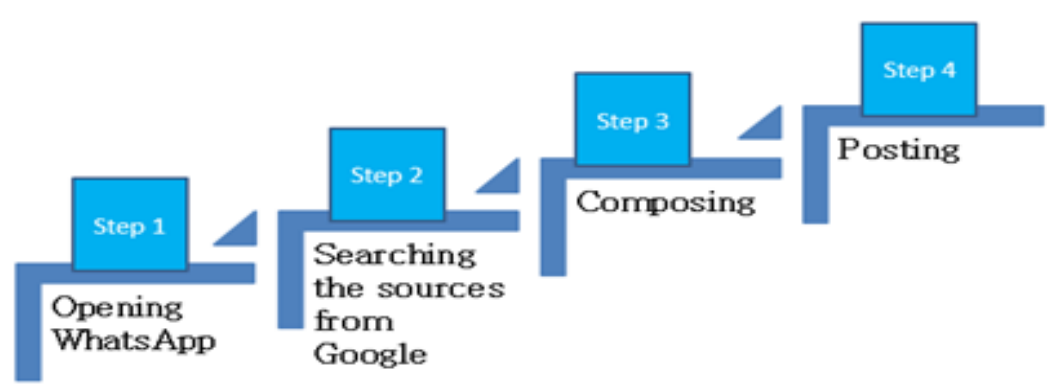

Figure 1: Model of E-writing through WhatsApp

These steps of E-writing lasted for 100 minutes by using the platform of WhatsApp with the total number of three times meeting of blended learning consisting of two online and one face to face meeting.

\section{Results and Discussion}

\section{Powerful impact of E-writing in improving critical thinking}

As explained in the previous section, the present study intended to investigate whether or not there were significant mean differences of critical thinking ability in writing exposition text between students who were taught by E-writing method and traditional method. To carry out the inquiry, the primary data were involved, i.e., the result of pre-test and post-test administered to both experimental and control group. Subsequently, the result of each test was scored by using the Holistic Critical Thinking Scoring Rubric developed by Facione and Facione (2011), who also suggest that the aspect to be assessed was focused on reasoning rather than the craftsmanship. In addition, the scoring rubric which ranks from 1-4 represents 1) significantly weak, (1) unacceptable (2), acceptable (3), and strong (4).

Each group of the present study was categorized into small group at which only experimental group having given E-writing Method. After having been scored by two raters and with the assistance of SPSS 23, the descriptive analysis of the data was summarized into Table 1 below:

Table 1: Descriptive analysis of Pre-test and Post test

\begin{tabular}{cccccc}
\hline $\begin{array}{c}\text { Name of } \\
\text { Group }\end{array}$ & Method & Min. & Max. & Mean & $\begin{array}{c}\text { Standard } \\
\text { Deviation }\end{array}$ \\
\hline
\end{tabular}




\begin{tabular}{ccccccc}
\hline Pre-test & Experiment & E-writing & 1 & 3 & 2,30 & 0,571 \\
& Control & Traditional & 1 & 3 & 1,80 & 0,834 \\
Post- & Experiment & E-writing & 2 & 4 & 3,60 & 0,598 \\
test & Control & Traditional & 1 & 3 & 2,30 & 0,657
\end{tabular}

As can be seen in Table 1 above, the mean of post-test obtained by both group was significantly different. In addition, the mean score of experimental group (3.60) was higher than the control group had (2.30). This statistical information led to the deduction that there was a significant different of critical thinking ability between students who were given Ewriting method and traditional method of writing.

After analyzing the data descriptively, the subsequent step was to test NGain scores, obtained from the data of pre-test and post-test by using SPSS 23. The reason was that the present study had to meet a credible research. Table 2 below presents the descriptive analysis of NGain score percent:

Table 2: The NGain score of Critical Thinking Ability

\begin{tabular}{lcccccc}
\hline \multicolumn{1}{c}{$\begin{array}{c}\text { Name of } \\
\text { Group }\end{array}$} & Method & N & Min. & Max. & Mean & $\begin{array}{c}\text { Standar } \\
\text { Deviation }\end{array}$ \\
\hline $\begin{array}{l}\text { Experiment } \\
\text { al }\end{array}$ & E-writing & 20 & 00.00 & 100.00 & 78.33 & 33.81 \\
Control & $\begin{array}{l}\text { Traditiona } \\
1\end{array}$ & 20 & -200.00 & 66.67 & -1.67 & 83.23 \\
& & & & & & \\
\hline
\end{tabular}

The NGain score percent of Critical Thinking Ability in Table 1 above is similar to the result of descriptive analysis of pre-test-and post-test (see Table 1). The NGain score of critical thinking ability obtained by Experimental group (78.33\%) was higher than critical thinking ability achieved by Control group was. To follow the category of NGain effectiveness, the NGain percent of 78.33 which implied that the method of E-writing is effective in improving students' critical thinking in writing exposition text. It can be assumed that E-writing method implemented to experimental group offered more powerful impact towards the ability of students' critical thinking. Figure 1 below presents the NGain score differences of Experimental group and Control group. 


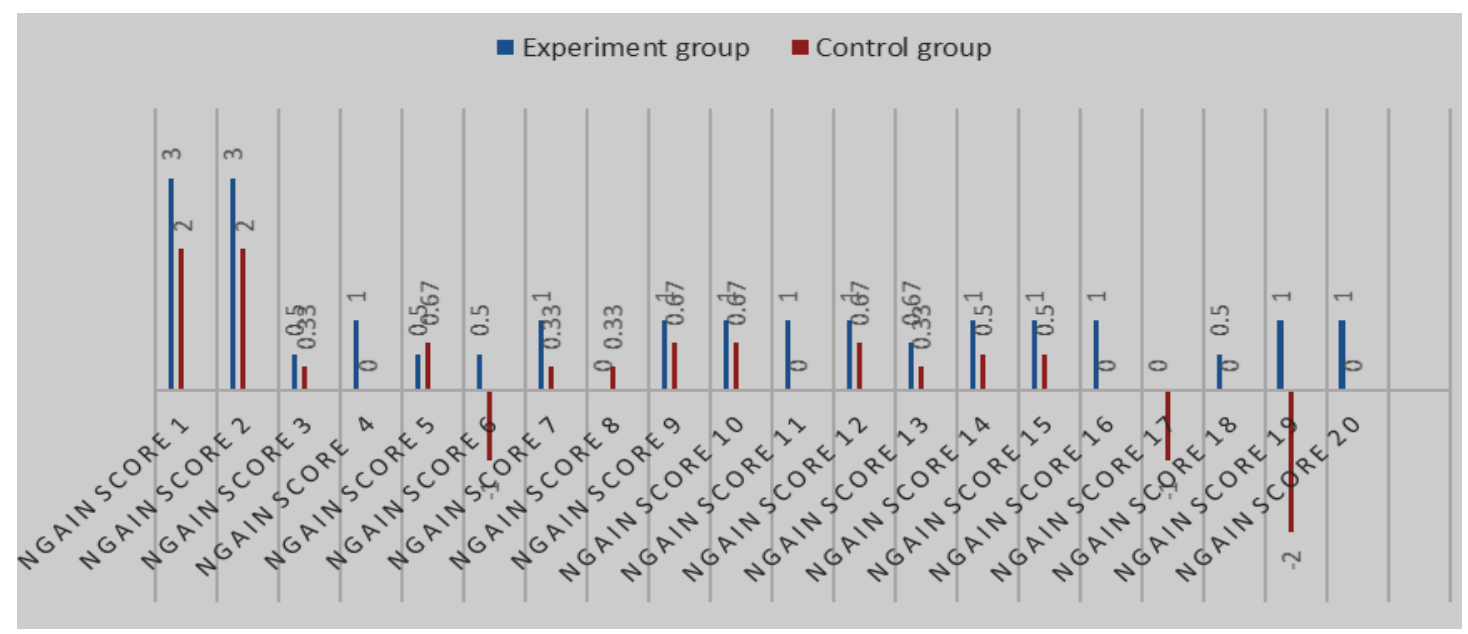

Chart 1: NGain score of Experiment group and Control Group

The forthcoming part was to test the normality of NGain scores as a way to determine whether data of NGain score had a normal distribution or not. Obviously, the result did not committed the normal distribution; both Shafiro Wilk and Kolmogorov Smirnov obtained the value of sig. $<0.005$ for experiment group and control group, as can be seen in Table 3 below:

Table 3: Test of Normality

\begin{tabular}{lllllll}
\hline $\begin{array}{c}\text { Name of } \\
\text { Group }\end{array}$ & \multicolumn{2}{c}{ Kolmogorov-Smirnov } & \multicolumn{3}{c}{ Shapiro-Wilk } \\
& Statistics & df & Sig. & Statistics & df & Sig. \\
\hline Experiment & 0.389 & 20 & 0.000 & 0.676 & 20 & 0.000 \\
Control & 0.308 & 20 & 0.000 & 0.761 & 20 & 0.000 \\
\hline
\end{tabular}

The result presented in Table 3 above led to the use of non-parametric measurement; and finally, based on the Mann Whitney calculation, the mean of NGain scores was different significantly. The value of Man Whitney test was indicated by asymp. Sig (2-tailed test).

As the present study resulted in asymp. Sig (2-tailed test) $=0.000<0.05$, it was clear that Man Whitney test value is less than $\alpha=0.05$. This resulted in the decision of accepting hypotheses, that is, there was a significant mean difference of critical thinking ability in writing exposition text between Experiment Group and Control Group. Consequently, the result of the finding showed that E-writing is effective in increasing students' critical thinking in writing exposition text.

The findings of study aforementioned became a contended answer for the research question of the present study, that is, Is there any significant mean differences of critical 
thinking ability in writing exposition text between students who were taught by E-writing and those who were not. The evidence of the descriptive statistics of different means reflected by NGain score arrived at the desired expectation; experiment group had a more prominent performance than control group had. Furthermore, it was supported by the fact that the mean of NGain scores were significant different between experimental group and control group indicating that the use of E-writing is effective in increasing the students' ability of critical thinking in writing exposition text. The finding uncovered not only the improvement of critical thinking but also their writing skill, which was consistent with the studies conducted by experts (Pu \& Evans, 2019; Lu \& Xie, 2019; see also Slater et al., 2017). In short, experiment group outperformed control group in term of critical thinking ability in writing exposition text.

Based on the statistical value aforementioned, it was fair to say that the increase of students' critical thinking ability caused by the implementation of E-writing. So that it can be assumed that students responded positively to changes the traditional teaching and learning strategies. Thus, E-writing provided a positive impact towards the increase of students' critical thinking ability in writing exposition text which was in line with the result of previous study conducted by Sharadgah (2014), and Ebadi and Rahimi (2018).

\section{Why does E-writing assist students' critical thinking?}

Due to the fact that E-writing offered powerful impact in improving students' critical thinking in writing exposition text, this study provided many reasons:

First, E-writing provided students a big opportunity in determining what to believe and what to do (Ennis, 1993). Students, who were given prompt writing, before or during classroom, would think fast in selecting the topic of essay because all of the information were easy to get; only by dragging and clicking, the desired sources comes up. Furthermore, searching the sources as well as designing their work became a routine conduct. In doing the task, they also had to make a decision in determining the website or blog containing the intended information. That was not all, the students were encouraged to determine the style of writing leading to an innovative work (see Figure 2 and Figure 3). Hence, this virtual environment fostered students in designing a framework to enhance their critical thinking ability; and help students with their selection of content and modes of expression (Andrew, 2009). 


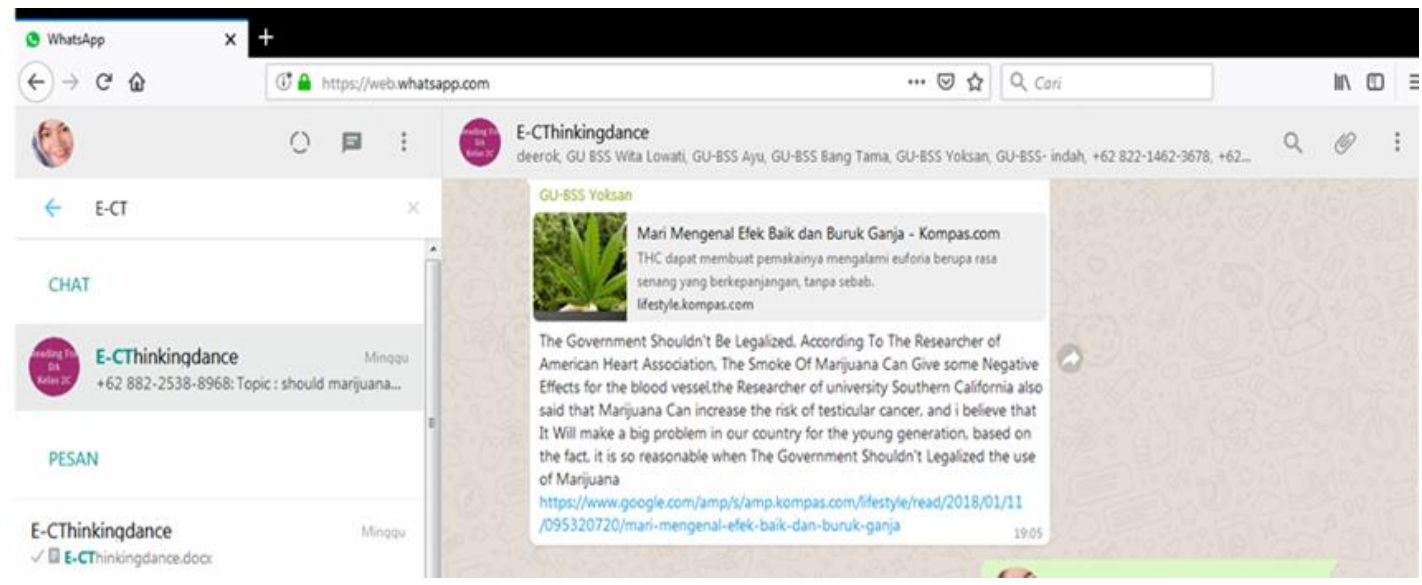

Figure 2. Student's writing task on WhatsApp

Second, the implementation of E-writing endorsed students to evaluate and synthesize (Mohd-Ali et al, 2013) the sources in order to make a sharp decision. Due to the large amount of sources provided by search engine, the process of E-writing forced students to conduct evaluation in selecting the desirable sources. Also, students were struggled to seek the intended sources that would fit their task; consequently, at this stage, the process of rejecting and accepting the sources occurred. Beyond that, students were also required to evaluate their own work in term of readability and its grammatical error in a very short time. Beyond that, E-writing was also provided student the ability to synthesize all sources. The sources obtained from Google search were vary; thus, students must be able to form all sources into a brief but meaningful, reasonable, and "effective argument" (Chafee et al, 2014) as can be seen in Figure 3. Like the ability to evaluate, synthesizing is categorized into higher order thinking level as part of Bloom Taxonomy (Setyarini et al., 2018). 


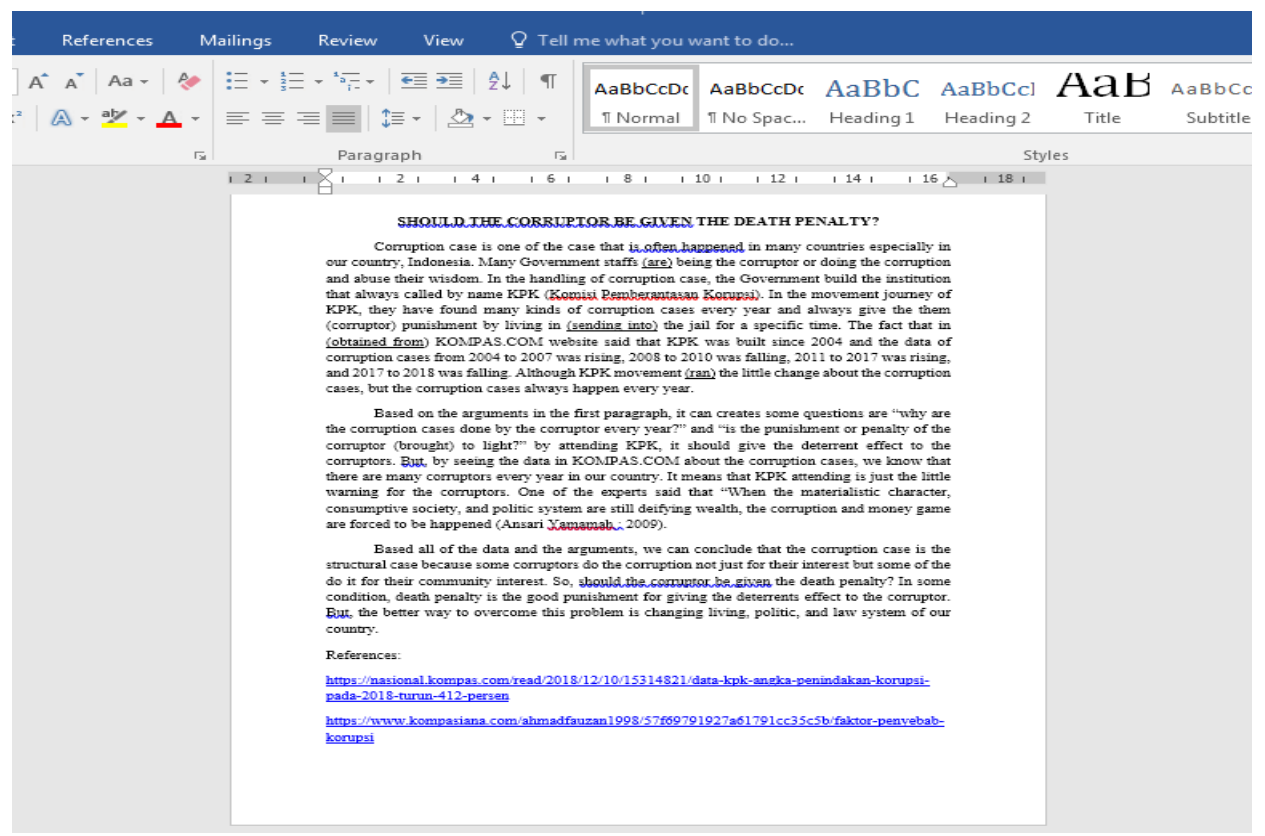

Figure 3. Students' writing task sending via WhatsApp

Third, E-writing provided an array for students to craft the academic written work and enable all of students to ignite their active learning that led to creative thinking. Moreover, supported by the need of innovative work in writing, they could produce their work in such a way which resulted in an outstanding written work highlighting students' academic attitude. Thus, the use of E-writing was really helpful for students; they saw E-writing as "a beneficial rather than threatening force" (Djiwandono, 2019).

\section{What does the result imply?}

It has been clear enough that the findings of the present study scrutinized the powerful impact of E-writing method in increasing students' critical thinking in writing exposition text. By referring to The Holistic Critical Thinking Scoring Rubric - HCTSR (Facione \& Facione, 2011), students who were taught by using E-writing had the variety of critical thinking ability of acceptable (2) and Strong (4) as given Table 1. In contrary, students who were given traditional writing were lag behind because their critical thinking ability held the rank of weak (1) and acceptable (3). It was convinced that the students in experimental group outperformed those who were in control group.

In general, the students' critical thinking encompassed ability to offer or analyse as well as evaluate major alternative viewpoints. It can be seen in Figure 2 and Figure 3, students' innovative work enclosed the references as a result of interpreting evidence. In detail, the 
ability of students' critical thinking in experimental group after being given E-writing method can be categorized as Strong (4) for many reasons:

“1) Accurately interprets evidence, statements, graphics, questions, etc.; 2) Identifies the most important arguments (reasons and claims) pro and con;3) Thoughtfully analyses and evaluates major alternative points of view; 4) Draws warranted, judicious, non-fallacious conclusions; 5) Justifies key results and procedures, explains assumptions and reasons; and 6) Fair-mindedly follows where evidence and reasons lead (The Holistic Critical Thinking Scoring Rubric HCTSR, Facione \& Facione, 2011)".

It is not exaggerated to say that E-writing as a virtual education system or Learning Management System has been committed to be used as vehicle to promote critical thinking skill (Alsaleem, 2013; Gharib, et al., 2016; Ta'amneh, 2017; Çalik, \& Karataş, 2019; Zaenudin, et.al., 2019). The study also might be illuminating for the teachers to heighten their sense of the importance of E-writing as a prominent strategy (Kavaliauskiene, et al, 2013) to increase students' critical thinking. Meanwhile, the students grasped an opportunity to become a creative thinker and strengthen their motivation (Andrew, 2009).

Despite the fact that the present study uncovered the significant mean differences of critical thinking ability between students who were taught by E-writing method and those who were given a treatment of traditional writing, the challenge might arise from the implementation of E-writing method. As E-writing occurred in the environment where the internet is available, the online learning was hampered by the availability of internet especially for the students who stayed in a remote area. To anticipate the bad condition, therefore, the present study also included blended learning with the involvement of online and face to face meeting, as well as flipped learning (Zainuddin et al., 2019).

The elaboration aforementioned indicated that the present study provided the thorough information. It has been clear enough that the findings of the study scrutinized the powerful impact of E-writing method in increasing students' critical thinking in writing exposition text. In other words, E-writing was effective in improving students' critical thinking in writing exposition text. 


\section{Conclusion}

This study has successfully explored the result of statistical measurement toward the hypotheses "whether or not there were a significant mean difference of critical thinking ability between students who were taught by E-writing method and those who are not". The research findings uncovered that the mean of NGain score obtained by experimental group was higher than control group did. After being calculated, the result of Mann Whitney is asymp. Sig (2-tailed test) $=0.000<0.05$. It suggested that there was a significant different in term of means score of NGain because Man Whitney was less than $(\alpha=0.05)$. The finding of the study provided a desirable evidence that students' critical thinking ability increased due to the great influence of E-writing method.

These expected findings were caused by the involvement of internet environment at which it provided several impacts. Among other, E-writing catered students to demonstrate their critical thinking ability by doing what to believe and what to do; E-writing trained students with the skill of synthesizing and evaluating the sources to craft a meaningful and logical decision; and E-writing facilitated students' creative thinking which resulted in innovative written task.

It was undeniable that the finding of the present study had a great significant toward the nuance of related issue; to a great extent, the method of E-writing might become a potential embryo in the establishment of permanent virtual education system or Learning Management System (LMS). Thus, it is suggested for further research to carry out the research on the use of affordable electronic devices as well as its application that can be used as a learning aid.

Finally, it is suggested for EFL teachers to implement E-writing through WhatsApp and utilizing others application that is available on smartphone to improve students' critical thinking ability in writing exposition text. Meanwhile, further research is recommended to broadly uncover the related issue in order to obtain more desirable result.

\section{Acknowledgements}

We would like to express our gratitude to Ministry of Research, Technology, and Higher Education, Republic of Indonesia, for the 2019 research fund to the writers.

\section{References}

Alazemi, A. F., Sa'adi, I.T., \& Al-Jamal, D.A. (2019). Effects of digital citizenship on EFL students' success in writing. International Journal of Learning, Teaching and Educational Research, 18 (4), 120-140 https://doi.org/10.26803/ijlter.18.4.7. 
Alsaleem, B.I.A. (2013). The effect of "Whatsapp" electronic dialogue journaling on improving writing vocabulary word choice and voice of efl undergraduate Saudi students. Arab World English Journal (AWEJ) - INTERNATIONAL PEER REVIEWED JOURNAL. 4(3), 213-225.

Andrew, M. (2019). Deepened mirrors of cultural learning: expressing identity through ewriting. CALICO Journal. 26(2), 324-336. Retrieved from https://www.jstor.org/stable/calicojournal.26.2.324

Brodahl, C., Hadjerrouit, S., \& Hansen, N.K. (2011). Collaborative writing with web. 2.0 technologies: education students' perception. Journal of Information Technology Education: Innovation in Technology, vol. 10, Retrieved from http://www.jite.informingscience.org/documents/Vol10/JITEv10IIPp073103Brodahl948.pdf

Çalik, M., \& Karataş, F. Ö. (2019). Does a "science, technology and social change" course improve scientific habits of mind and attitudes towards socioscientific issues? Australian Journal of Teacher Education, 44(6). Retrieved from http://dx.doi.org/10.14221/ajte.2018v44n6.3

Carmichael, E., \& Farrell, H. (2012). Evaluation of the effectiveness of online resources in developing student critical thinking: review of literature and case study of a critical thinking online site. Journal of University Teaching and Learning Practice, 9(1), 4.

Chafee, J., McMahon, C. \& Stout B. (2015). Critical thinking thoughtful writing- a rhetoric with reading. Sixth edition. Stanford: Cengage Learning.

Cohen, L., Manion, L., \& Morrison, K. (2011). Research method in education. 7th Edition. Routlede.

Creswell, J.W. (2018). Research design: qualitative, quantitative, and mixed methods approaches.Fifth edition. Sage Publication Inc.

Djiwandono, P.I. (2019). How language teachers perceive information and communication technology. Indonesian Journal of Applied Linguistics 8(3), 608-616. doi: 10.17509/ijal.v8i3.15260.

Ebadi, S. \& Rahimi, M. (2018). An exploration into the impact of WebQuest-based classroom on EFL learners' critical thinking and academic writing skills: a mixedmethods study. Computer Assisted Language Learning, 31(5-6), 617-651. https://doi.org/10.1080/09588221.2018.1449757.

Ennis, R.H. (1993). Critical thinking assessment. Journal Theory Into Practice. 32(3), 179186. https://doi.org/10.1080/00405849309543594

Facione, P.A., \& Facione, N.C. (2011). Holistic Critical Thinking Scoring Rubric in Insight Assessment. Millbrae CA: The California Academic Press. Retrieved from https://www.insightassessment.com/Resources/Teaching-Training-and-LearningTools/Holistic-Critical-Thinking-Scoring-Rubric-HCTSR

Fung, D. \& Howe, C. (2014). Group work and the learning of critical thinking in the Hongkong secondary liberal studies curriculum. Cambridge Journal of Education 44(22). https://doi.org/10.1080/0305764X.2014.897685.

Fung, D., To, H., \& Leung, K. (2016). The influence of collaborative group work on students' development of critical thinking: the teacher's role in facilitating group discussions. Journal Pedagogies: An International Journal Volume 11, 2016 - Issue 2: Moralities in 21st Century Pedagogies 144-166, 2016. Retrieved from https://doi.org/10.1080/1554480X.2016.1159965 
Idris, R., Ariffin, S.R., \& Ishak, N.M. (2009). Kemahiran generik dalam kemahiran pemikiran kritikal, penyelesaian masalah dan komunikasi pelajar Universiti Kebangsaan Malaysia (UKM). Malaysian Journal of Learning and Instruction (MJLI) 6 , 103-140.

Kavaliauskienė, G., Suchanova, J., \& Veličkienė, D. (2012). Students' reflection on writing in esp. Santalka: Filologija, Edukologija, 20(2), 3.

Kunkun, K. (2015). Validity considerations in designing a writing test. Studies in Literature and Language 10(5), 19-21. https://doi.org/10.3968/6957.

Lu, D., \& Xie, Y. (2019). The effects of a critical thinking oriented instructional pattern in a tertiary EFL argumentative writing course. Higher Education Research \& Development 38(5) 969-984. https://doi.org/10.1080/07294360.2019.1607830

Mohd-Ali,S., Harun, H., Mahir, N.A., Massari, N., Mat Saad, N.S., \& Simin, K. (2018). Meeting the demands of the 21st century English language learning through pbl-lccraft. GEMA Online ${ }^{\circledR}$ Journal of Language Studies. 18(2), 255-266. http://doi.org/10.17576/gema-2018-1802-17

Paul, R. \& Elder, L. (2010). The Miniature Guide to Critical Thinking Concepts and Tools. Dillon Beach: Foundation for Critical Thinking Press.

$\mathrm{Pu}, \mathrm{S}$. \& Evans, M. (2019). Critical thinking in the context of Chinese postgraduate students' thesis writing: a positioning theory perspective. Language, Culture and Curriculum 32(1) 50-62. https://doi.org/10.1080/07908318.2018.1442473

Rohayati, D. (2017). Students' critical thinking in writing an English exposition text. Advance in Social Sciences and Humanities Research (ASSEHR), 82(3), 228-232. Ninth International Conference on Applied Linguistics (Conaplin).

Romagnuolo, A. (2015). Teaching English professional writing in an e-learning environment: an Italian case study. International Journal of Language and Linguistics, 2015; 3(6): 383-393.

Setyarini, S., Muslim, A.B., Rukmini, D., Yuliasri, I., \& Mujianto, Y. (2018). Thinking critically while storytelling: improving children's hots and English oral competence. Indonesian Journal of Applied Linguistics. 8(1), 189-197. https://doi.org/10.17509/ijal.v8i1.11480189

Scott, S. (2008). Perceptions of students' learning critical thinking through debate in a technology classroom: A case study. Journal of Technology Studies, 38(1), 2. https://doi.org/10.21061/jots.v34i1.a.5

Sharadgah, T.A.A. (2014). Developing critical thinking skills through writing in an internetbased environment. International Journal of Humanities and Social Science. 4(1), 169178.

Slater, W.H. \& Groff, J.A. (2017). Tutoring in critical thinking: using the Stases to scaffold high school students' reading and writing of persuasive text. Journal Reading \& Writing Quarterly Overcoming Learning Difficulties 33(4), 380-393. Retrieved from https://doi.org/10.1080/10573569.2017.1294516

Ta'amneh, (2017). The effect of using WhatsApp messenger in learning English language among university students. International Research in Education 2017, 5(1). 141-151.

Umar, I.N., \& Ahmad, N.H. (2010). Trainee teachers' critical thinking in an online discussion forum: A content analysis. Malaysian Journal of Learning and Instruction (MJLI) 7(1) 75-91.

Zainuddin, Z., Habiburrahim, Muluk, S., Keumala, C.M. (2019). How do students become self-directed learners in the EFL flipped-class pedagogy? A study in higher education. Indonesian Journal of Applied Linguistics. 8(3), 678-690. https://doi.org/: 10.17509/ijal.v8i3.15270. 